\title{
Literary Routes: Migration, Islands, and the Creative Economy
}

\section{Citation}

Lionnet, Françoise, and Emmanuel Bruno Jean-François. 2016. "Literary Routes: Migration, Islands, and the Creative Economy." PMLA 131 (5) (October): 1222-1238. doi:10.1632/ pmla.2016.131.5.1222.

\section{Published Version}

doi:10.1632/pmla.2016.131.5.1222

\section{Permanent link}

http://nrs.harvard.edu/urn-3:HUL.InstRepos:34786082

\section{Terms of Use}

This article was downloaded from Harvard University's DASH repository, and is made available under the terms and conditions applicable to Other Posted Material, as set forth at http:// nrs.harvard.edu/urn-3:HUL.InstRepos:dash.current.terms-of-use\#LAA

\section{Share Your Story}

The Harvard community has made this article openly available.

Please share how this access benefits you. Submit a story.

\section{Accessibility}




\title{
Literary Routes: Migration, Islands, and the Creative Economy
}

\author{
FRANÇOISE LIONNET AND EMMANUEL BRUNO \\ JEAN-FRANÇOIS
}

FRANÇOISE LIONNET teaches French, comparative literature, and African and African American studies at Harvard University, and she is distinguished professor of French and francophone studies and comparative literature at the University of California, Los Angeles. Her most recent books include Le su et l'incertain: Cosmopolitiques créoles de l'océan Indien / The Known and the Uncertain: Creole Cosmopolitics of the Indian Ocean and Écritures féminines et dialogues critiques: Subjectivité, genre et ironie / Writing Women and Critical Dialogues: Subjectivity, Gender, and Irony, both published by L'Atelier d'Écriture in Mauritius in 2012.

EMMANUEL BRUNO JEAN-FRANÇOIS is the Marian Trygve Freed Early Career Professor in the Department of French and Francophone Studies and an assistant professor of French and francophone studies and comparative literature at Penn State University, University Park. He is the author of Poétiques de la violence et récits francophones contemporains, forthcoming from Brill in 2017. His current and second book project focuses on contemporary Indian Ocean literary and cultural studies. ouvrez bien l'oreille

retenez bien votre souffle

d'une rive à l'autre le désastre en partage cette nuit ils ont annoncé la mort d'un des miens mon cousin happé par la vague broyé par les flots vorace l'océan s'est rappelé à nous comme à son habitude depuis qu'existe ce mur de haine

vérités de vaincus sous vide vérités quand même.

open big your ears

hold your breath

from one shore to the other disaster shared

last night they announced the death of one of ours

mycousin snapped up by a wave crushed by the water

voracious ocean it made its point as it has ever since the existence of this wall of hatred

truths of the vanquished in a void truths even so. ${ }^{1}$

-Soeuf Elbadawi, Un dhikri pour nos morts: La rage entre les dents

\section{Small Narratives, Significant Details}

W E ARE IN THE AGE OF BIG DATA, WHEN A MASSIVE HAUL OF STAtistics, captured every time we use the Internet, is mined to determine the contours of our social identities, to map our

(C) 2016 FRANÇOISE LIONNET AND EMMANUEL BRUNO JEAN-FRANÇOIS PMLA 131.5 (2016), published by the Modern Language Association of America 
moves, to pry into our conscious and unconscious wishes. Mastery of such computable, "objective" evidence has also become the goal of much research and education. But mining data and digesting data are not the same thing. Statistics are curated to fit research purposes, and the ever-narrower definitions of truth emerging from this strictly quantitative information overload make the teaching of critical approaches to literature a Sisyphean challenge.

The poetic and activist oeuvre of the Comoran artist Soeuf Elbadawi provides a luminous path up the hill. Aggrieved like so many "from one shore to the other" by the relentless clandestine migration crisis, he shows that it is a "disaster shared" widely (7), despite global silence about the almost daily tragedy of migrants' drowning in their attempt to cross between islands in his Indian Ocean archipelago of the Comoros, off the coast of East Africa. Audible or legible truth is always determined by questions of power, but the truths of the "vanquished" from an ultraperipheral region of the globe will remain hard facts, even when "void," negated, or curated out of official narrative to suit the state's policy objectives (28). Literature unsettles this selective ordering of knowledge, contributing alternative insights that illuminate other realities, the truths that cannot be quantified.

The qualitative and aesthetic goals of our interpretive disciplines provide a crucial counterpoint to the ostensibly unbiased but always incomplete numerical perspective. As scholars of francophone "minor transnationalism" (Lionnet and Shih) and postcolonial or transcolonial studies whose research intersects with many areas of the quantitative social sciences that also study cultural identity, mobility, migration, and the flashpoints of empire, ${ }^{2}$ we often need to explain what our literary approach contributes beyond what anthropologists, sociologists, political scientists, and legal experts already offer, all the more so now that some of these colleagues use literature, art, and film as examples of testimonials worth including in their empirical research and teaching. ${ }^{3}$ What can we, literary humanists, add to knowledge about the global transformations that have put diverse peoples, cultures, and languages into close contact over long historical periods?

Patterns of migration are accelerating. The United Nations estimates that one-sixth of the world's population will be migrants by the end of the next decade: one billion people by 2030 . Social scientists capture these numbers to understand population movement, to predict migration trends and the largescale problems they create, and to study the changes that emerge from the "globalization of biography" (Beck 73). Writers and visual artists, by contrast, give us the human interest stories that pull us into the concrete lives of individual migrants and their families. As humanists we are interested in the small narratives and significant details that give us the texture of human interactions in the contact zones of migratory flows. We want to understand what it means to be caught in such currents, whether as an agent of the colonial power or as a victim of its predatory reach. Why do so many brave the elements, in search of "hope and other dangerous pursuits," like the four migrants who risk their lives crossing the Strait of Gibraltar in the Moroccan American author Laila Lalami's novel? Why are they lured by images of an idealized elsewhere only glimpsed in the global media? How do we appreciate and evaluate experiences that cannot be captured by big data but that singular poetic images convey with exquisite precision and affective depth?

Large numbers only numb the senses and blunt our ability to respond. They do not convey the full impact of loss. Visual and verbal testimonials can. Poetry and tragedy, verses and incantations unquestionably do. The 2015 photograph of a drowned Syrian child on a beach in Turkey did more to mobilize the "good" people of the West about the crisis in the Mediterranean than the numerous news reports and dry statistics that only routinize 
and depersonalize the interminable disaster. The media spotlight in summer 2015 was trained daily on the swelling number of families and children afloat in the Mediterranean; on the migrants' camp at Calais, France; and on the border problems in Macedonia, Austria, Hungary, and elsewhere in continental Europe. But the poetic and theatrical work of Elbadawi reminds us that this crisis is a global phenomenon that reaches deep into the southwestern Indian Ocean and the Comoros. Of this group of islands, Grande Comore, Anjouan, and Moheli became independent in 1975, but Mayotte, the closest to Madagascar, voted to retain its colonial ties to France, making it an "ultraperipheral region of the European Union" ("Mayotte"). In 2011 Mayotte officially became the 101st department of France-and the fifth overseas department (DOM) - after a 2009 referendum in which the population voted overwhelmingly for a change of status that put it on an equal footing with the other DOM in the region, La Réunion, in the Mascarene Islands. Because of Mayotte's proximity to the other Comoro Islands, whose 800,000 inhabitants share languages, cultural practices, and religion with the 220,000 domiens who acquired full French citizenship in 2011, ${ }^{4}$ thousands of Comorans take to the sea to reach the shores of this "European" territory. They hope to escape dire circumstances in their own islands, whose "general revenue and living standards are ten times lower" than those of Mayotte, itself desperately poor and "saddled with 50 percent unemployment" (Bragard 193). Over the past two decades, thousands have drowned trying to make the crossing under cover of darkness in small, overcrowded fishing pirogues nicknamed kwassa-kwassa. ${ }^{5}$ Government reports of this tragedy suggest that between five hundred and one thousand Comorans die each year in the canal de la mort 'death channel,' many of them minors sent off by parents who think the children will not be expelled by French authorities, should they survive the fifty-mile journey from Anjouan to Mayotte (Torre). Even during periods of calm weather, when the intertropical winds are favorable, Comorans perish by the boatload trying to reach Mayotte.

In Un dhikri pour nos morts: La rage entre les dents 'A Dhikr for Our Dead: Teeth Clenched in Rage,' Elbadawi hears of a cousin's fate at sea on his local radio station, where the names of the ninety-eight people claimed that night by the waves are recited in a prayer

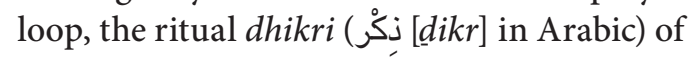
the book's title:

Un speaker égrenant le long chapelet des sinistrés se répète Inlassablement la Ilaha ill'Adhwahu la Ilaha ill'Adhwahu. ...

la Ilaha ill'Adhwahu nous n'avons rien demandé au Ciel imperturbable sauf Le droit de mourir en paix sur une terre de croyants....

la nouvelle est rude Quatre-vingt-dix-huit noms passés par-dessus bord Ils ont péri dans les flots Quatre vingt-dix-huit noms qui s'épellent comme autant de lames traversant ce corps d'insularité qui est nôtre

An announcer chants the names of the dead and repeats Tirelessly la Ilaha ill'Adhwahu la Ilaha ill'Adhwahu. ...

la Ilaha ill'Adhwahu we never asked anything from indifferent Heaven save The right to die in peace in a land of believers....

the news is rough Ninety-eight names lost overboard They met their death in the water Ninety-eight names that spell as many waves slicing into our body of islands

The narrator mourns the dead, commenting that one more body would have raised the count to ninety-nine, the number of names given in the Qur'an to God-a god who, he says, must have been asleep that night instead of protecting the migrants. He asks, "Où étais-tu Seigneur des Inconscients pour 
défier l'Impensable" 'Where were you God of the Unaware, the Lifeless, to prevent the Unthinkable' (9). Rebelling against God and the injustice of the world, he is not afraid of being sacrilegious: "Les gardiens de la foi m'accuseront de blasphème" 'The keepers of the faith will accuse me of blasphemy' (11). He laments the fate of his cousin, who was not religious and allowed himself to be lured by the mirages of the West. Elbadawi dissects the motivations and desires of the would-be migrants whom he insists on making real while deploring the priorities of the French evening news, "les lucarnes du 20h00" ' 8 o'clock news clips,' which neglects to mention the daily personal tragedy suffered by many local families. In official reports, the dead are rendered invisible and nameless, but Elbadawi's poetic language restores the secular nobility of an act of mourning and the dignity of those whom even God seems to have abandoned. His duty to the dead is to "nomme[r] l'horreur" 'name the horror' of these mass drownings and to consecrate the invisible water graves that swallow fellow Muslims who will never get a ritual burial (30).

How might his poetic intervention be truly heard by those who are addressed in the first line of the book, those willing to "open big their ears"? Elbadawi's subtitle, La rage entre les dents 'Teeth Clenched in Rage,' broadcasts his anger toward the powerful (God and the state) while also paying his respects to his relatives and fellow islanders. He is apostrophizing the inhabitants of his archipelago and the world at large, daring us to listen and take notice, even when the media will not. His short poetic volume is well distributed across francophone areas, largely because it is printed and marketed by Vents d'Ailleurs, a publishing house based in La Roque d'Anthéron, in the south of France, that has been bringing these cultural ailleurs 'elsewheres' to the attention of the world, perhaps to the detriment of local efforts to develop expressive pathways and create job opportunities for the youth tempted by dreams of emigration. How then to reconcile the contradictions of the French departmental system, which includes access to both the state-owned television station denounced by the text and the publishing house that gives Elbadawi a platform for voicing and disseminating the denunciation? On the one hand, the system obfuscates the plight of local migrants, routinely excluding them and their families from the news, but, on the other, it provides the print vehicle by means of which their stories can be shared with a global audience. ${ }^{6}$

Acutely aware of these ethical dilemmas, Elbadawi returned to Mayotte in 2005 after having lived and performed in Paris since the early 1990s. He actively contributes to the theatrical life of the community and the university in Mayotte, while occasionally being censured for his outspokenness by more pious compatriots as well as secular expatriates and French authorities in his native city. He has returned home, but there is no doubt that Europe figured as a site of mediation, enabling his insertion into a global creative economy that began with his work as a journalist at Radio France Internationale and continued with his stage and filmic productions in Paris, Limoges, Marseille, and Belgium. The range of his interventions makes him a powerful transnational figure from the peripheries of the African and European continents, with a distinct voice that tirelessly questions the political elite while referring to it sarcastically as the "Maître des Possédants" 'The Wealthy's Master' $(12,31)$.

Elbadawi's physical displacement to Europe and later repatriation mark out a route of departure and return increasingly common for many intellectual and economic migrants. After living as a global writerperformer in a Western center Elbadawi goes back to his home country to become a minor transnational creator whose work engages with and critiques multiple overlapping temporalities and identities (secular and religious, domien and independent, European 
and African) while also foregrounding the disjunctive geographies of the French Indian Ocean region and its Muslim populations. For Françoise Lionnet and Shu-mei Shih, the global and the transnational represent two spatiotemporal concepts:

Whereas the global is ... defined vis-à-vis a homogeneous and dominant set of criteria, the transnational designates spaces and practices acted upon by border-crossing agents, be they dominant or marginal. The logic of globalization is centripetal and centrifugal at the same time and assumes a universal core or norm ... [that] produces a hierarchy of subjects between the so-called universal and particular. ... The transnational... can be conceived as a space of exchange and participation ... where it is possible for cultures to be produced and performed without necessary mediation by the center.... The transnational can occur in national, local or global spaces across different and multiple spatialities and temporalities.

Elbadawi's writing indicates the tensions between the centripetal pull of homogenizing globalization and the unscripted, multidirectional creativity of transnational sites of production. His publications and performances open a window on the work that literature performs in the world understood as an assemblage of temporal, spatial, and cultural folds rather than as a sphere whose orbit attracts difference to its core only to neutralize it. Un dhikri pour nos morts remaps the shifting shorelines, borders, and tectonic plates that disrupt archipelagic becomings in the Comoros. But its 2013 publication in France also points to the widening gap between local and global publishing resources that continues to prevent peripheral voices from being heard and thus from sharing the significant aspects of lives typically hidden under the mass of numerical data that can only tell a disembodied story of contemporary dispossession.

As we will discuss in the final section of this essay, Vents d'Ailleurs is an alterna- tive French publisher that emphasizes hearing different accents and listening to other voices. It describes the mission of its book series Fragments as bringing into print "autant de voix surtout pour contourner la prétention de l'écrit à délimiter le réel" 'the many voices that allow us to get around the pretention that writing alone demarcates reality' ("Fragments"). Challenging established conventions of literary value and dominant paradigms of the creative economy, the press promotes an idea of writing as transformative intervention in the world, a belief that literature can make a difference in the way lives are perceived, recognized, and valued. It exemplifies the type of transnational space theorized above.

Can our analytic disciplines contribute, in turn, to rethinking the means of representing and disseminating perspectives from the "ultraperipheries"? How good are we, as literary critics, at enhancing awareness of human rights issues and furthering epistemological equality? ${ }^{7}$ What is the critical effectiveness of literature in the world as an agent of cultural change, and how do we heighten appreciation for stories and storytelling, for the insatiable human desire to make sense of the world through narrative?

We will consider these questions in terms of the positional advantages that accrue to those, like Elbadawi, whose participation in the creative economy of the metropole gives them a platform from which to make visible the lives, and audible the stories, of their compatriots. These stories can contribute to an ever more inclusive approach to world literature, prodding us to reflect on both the work literature does now and the material conditions of its reception along the many byways it must travel to reach reviewers and readers who are open to listening to alternative voices.

\section{Minor Locations, World Literatures}

Doris Sommer demonstrates, in The Work of Art in the World, that creativity and critical 
thinking are two sides of the same coin. She presses into service the thinkers and practitioners who provide "instructions for disarming hierarchies through cultural interventions" (147). Arguing that "an optimism of the will, beyond the despair of reason, drives life toward social commitments and creative contributions," she shows how artists, thinkers, and citizens become democratic cocreators of culture and agents of civic change when "the disruptive energy called art" arrests the reader's or viewer's attention, focusing it on social needs (6-7). Her bracing analysis and defense of aesthetic play and pleasure are urgent reminders of the vital importance of techne and the freedom to make and share art-even, or especially, in difficult circumstances.

But, we must also ask, when the tools for disseminating literary art from "a small place" ${ }^{\prime 8}$ associated primarily with exotic tourism are in the hands of publishers who do not occupy the same locations as the writers, are the writers' contributions blunted or compromised? Is their writing less likely to have meaning in the world of those it attempts to represent? In the wake of the restructuring of the publishing industry and its distribution circuits, critics have recently reopened a debate that began with the rise of postcolonial studies in the 1980s. New questions about editorial control, writers' self-presentations, and linguistic diversity are asked now that increased centralization has also provoked pushback and inspired diversification. Widespread Internet access in the peripheries has enabled the emergence of small presses that successfully target a different and loyal readership.

When Frieda Ekotto and Kenneth Harrow, in their introduction to Rethinking African Cultural Production, reflect on the fact that "African literature and cinema are being produced increasingly by writers and filmmakers who live abroad," they make the assumption that "publishers whose titles reach global markets typically focus on the metropolitan centers of the global North."
In the main, this is true, but the picture is more complex and varied, since, as they also explain, "only a percentage of those whose works are widely diffused as 'world literature' or 'world cinema' live solely in Africa" (1; our emphasis). The word solely hints at the circular routes of influential authors like Elbadawi who give back by coming back, if only temporarily in some cases, and who can have an impact in regional publishing and distribution circuits, since they occupy a privileged position in relation to those who cannot travel in and out of their native countries. When the intellectual and cultural cachet of so-called indigenous and minor writers is absorbed into Western metropolitan markets, their works present and represent different regions, providing a more inclusive definition of world literature. Yet the geographic implications of writers' migration pathways from peripheral to central locations and back, coupled with their quest for publication and distinction in the West, have given rise to new questions about the extrinsic factors that drive artistic and literary achievement, from the changing dynamics of the book market and digital publishing to the "rise of the creative class," a situational phenomenon with distinct regional advantages in the increasingly diversified knowledge economy.

The fact remains that the current visibility of postcolonial literature produced and disseminated by Western centers of knowledge is sufficient neither to disrupt power disparities nor to destabilize the universalist definitions of literature tied to and reinforced by the tastemakers and gatekeepers who control the conditions of evaluation and production of that literature. ${ }^{10}$ Visibility tends to create a reductive equivalence between world literature and a collection of representations of and from distant places. This equivalence leads to a flattening of the field that reinforces the logic of inequality; that skews the legibility of alternative aesthetic, thematic, and formal criteria; and that ascribes arbitrary value 
to notions of originality that heighten the opposition between individual and collaborative authorship. Sarah Brouillette makes this point when she reframes Graham Huggan's critique of the "'strategic exoticism' that pervades postcolonial writing as authors attempt to show that they understand the ways in which they are being asked to present the Third World or global South to a presumably apolitical audience" (Postcolonial Writers 5). She suggests that it is "more fruitful to understand strategic exoticism, and ... postcolonial authorial self-consciousness ... as comprised of a set of literary strategies" that are shared by writer and reader in their common goal to "negotiate with, if not absolve themselves of, postcoloniality's touristic guilt" (7). The reception of variously positioned authors is constrained by market forces and expectations, but, as Brouillette points out, audiences will have "radically different definitions of literary value" (9), based on the perceived political commitment or provenance of a given author, whose choices can also exhibit a "form of responsive authorial agency" (177). In addition, when a writer is simultaneously located in multiple sites of enunciation, audiences will diverge in their appreciation of the work, depending on the stakes they have in the overall aesthetic or political project of the text and its situational relevance.

What is included in the influential category of world literature is thus colored by these ideological or systemic mechanisms of discrimination, incorporation, and distribution. This partially explains, for example, why the frameworks that scholars use to reflect on the place of francophone literatures in the curriculum or the book market have been extensively discussed since the publication of Michel Le Bris and Jean Rouaud's 2007 manifesto "Pour une littérature-monde en français." This document unconvincingly advocates the death of francophonie in favor of littérature-monde en français 'world literature in French,' only proving the blindness of centripetal discourses that ignore the ethical stances and aesthetic or linguistic practices of minor authors. ${ }^{11}$ A more legitimate study of littérature-monde would require that we reconsider the range of subject positions made possible by globalization and therefore conditioned by overlapping temporal, spatial, and linguistic milieus (Lionnet, "Universalisms" 204, 216). To do justice to these complex environments, we must take into account the alternative epistemologies, heterogeneous literary contents, and unconventional editorial strategies put forward by the publishers of writers who question static oppositions between center and periphery and who challenge the exclusionary definitions of the world that pass for universal in Parisian editorial circles.

The division between the local and the global has never been intellectually viable for multitudes of border-crossing cultural agents. Despite literary historians' and area studies specialists' compartmentalization of the world into discrete disciplines that reinforce difference, the interpenetrating dynamics of ever-multiplying contact zones demand the broadening of creative and critical landscapes to accommodate authors like Elbadawi. There are many other border-crossing writers, such as Lindsey Collen (South Africa and Mauritius), Ananda Devi (Mauritius and France), Fatou Diome (Senegal and France), Aminatta Forna (Scotland and Sierra Leone), and Michèle Rakotoson (Madagascar and France), who also exemplify forms of translocality capable of undermining notions of static belonging. ${ }^{12}$

This mode of existence in the world confirms Jean-Luc Nancy's vision of the monde's ever-evolving nature: ${ }^{13}$ "le monde n'est monde qu'à se transformer sans cesse, à se plier et déplier, multiplier en mondes qui tout à la fois s'excluent et s'intriquent, qui se métamorphosent aussi chacun pour soi et entre eux" 'the world is world only to the extent that it keeps on transforming itself, as it folds and unfolds, duplicating itself into a multiplicity of 
worlds that alternately diverge and converge, simultaneously undergoing individual and reciprocal mutations' (89). Édouard Glissant's notion of the Tout-monde similarly invokes multiplicities engaged in dialogic transformation: "J'appelle Tout-monde notre univers tel qu'il change et perdure en échangeant et, en même temps, la 'vision' que nous en avons. La totalité-monde dans sa diversité physique et dans les représentations qu'elle nous inspire" 'I call Tout-monde our universe as it changes and endures through interchange, together with our "vision" or understanding of it. It is the world in its totality, its physical diversity, as well as our representations of it' (176). In these two capacious, inclusive definitions, the center-periphery binaries are not banished, but their borders are blurred by new geocultural imaginations. This explains the widening appeal of authors who move to the center to avail themselves of powerful institutions without compromising their artistic goals. As Lionnet has shown, the globally acclaimed Devi, grande dame of Mauritian letters, subtly ironizes the universalist ideology of the 2007 manifesto that she did, however, sign (Lionnet, "Littérature-monde" 130). Yet her gently subversive engagement with the French critical establishment has escaped its notice, no doubt because minor francophone authors are often denied this ironic dimension of critique by reviewers blinded by what they consider to be the merely "exotic" dimensions of her writing. Thanks to this contingent position of enunciation, a writer now considered major but linked to a minor location can use her voice as an ambiguous site of resistance that questions authority and conventions from within.

Whether chosen by the author or imposed by a metropolitan publisher, the precise presentation of the author's home geography depends on rhetorical strategies and the effect they have on the reader's sense of identification and wonder. Yet proponents of littérature-monde tend to peg authorial identity as fixed and rooted rather than dynamic and linked to multiple and simultaneous spaces of belonging. ${ }^{14}$ Writers know that they must fulfill several conditions in order to generate global appeal for their geocultural content and aesthetic choices. They become more conscious of the political and economic logics of the market as they strive to gain access to prestigious editorial systems and distribution circuits. In her interview with the British scholar Julia Waters, Devi explains how francophone writers covet the legitimation and rewards associated with entry into top Parisian houses like Gallimard, Grasset, and Seuil. But while referring to her own trajectory-from a hometown press in Mauritius to Nouvelles Éditions Africaines in Abidjan, Ivory Coast, to the Gallimard series Continents Noirs and on to the renowned series Collection Blanche, in Gallimard's NRF portfolio-she underscores how much more difficult it is for writers from the global South to be accepted into these institutions:

I'm sure that you'll understand that after twenty years of "hell", getting published with Gallimard, Grasset or Seuil represented a kind of recognition that's in a completely different league from publishing with Harmattan or even Dapper. Personally, I know that they're just names, that this prestige can be a bit excessive, that smaller publishing houses have their merits and that I owe them a great deal. But, in terms of readership, it makes a huge difference to say that you're an author who's published by Gallimard, and the recognition is immediate. Indeed, this is even more significant for a writer from Mauritius! ... It represents a form of legitimation in the eyes of the public, which is much more difficult for authors from the Southern hemisphere to achieve than for others. We are aware that our works are no less good than those of others who find publishers more easily. But we start off with a definite handicap, and that's why, along the line, there is a lucid acceptance of the compromises entailed. (Devi 119) 
Devi makes clear that regardless of publishers' ideological or economic motivations, the recognition bestowed on writers of the South by publishers from the North testifies to the gradual opening up of the guild of major editors, who now offer broader opportunities to writers eager to occupy a more visible place on the global francophone literary stage. This new inclusivity can spell a form of epistemological justice as readers become more aware of the stakes of representation and access. By insisting on her own desire to reach a wide readership, Devi foregrounds a vital aspect of world literature often ignored in discussions and definitions of the field. She reveals that authors self-consciously write with this imagined readership in mind; and, problematic or not, this fact helps determine the way they present themselves and conceptualize their individual contributions to the creative economy.

\section{Local Tongues, Global Languages}

Many other francophone writers negotiate similar pathways into the literary marketplace, producing locally grounded writing with global ambitions. Their publication strategies contribute to the processes of recognition, translation, and circulation that are now central to the influential theories of world literature first articulated by David Damrosch in What Is World Literature? Their transregional strategies include practices of mutual support and empowerment that boost visibility and circulation while also providing effective ways of interrogating extant notions of universalism, such as those critiqued by Nancy and Glissant. Regional solidarity can protect writers from easy cooptation into the ostensibly inclusive yet actually unequal logics of the metropolitan system, since, as Brouillette points out, "for the postcolonial writer the problem is the politicization of incorporation into a discredited global sphere. The politicization is something they face and acknowledge, but do not necessarily sanction" (Postcolonial Writers 4).

In the Mascarene and Comoro Islands of the Indian Ocean, as in the Polynesian islands of the Pacific, collaboration and networking have become instrumental in nurturing conversations, performances, and publications that make francophone writers more visible and strengthen the value of their vision of the world, beyond their insular shores and across a variety of critical terrains. The writers' ethical resistance to centripetal dynamics of power is a strong counterweight to neocolonial definitions of the exotic and to often internalized stereotypical representations of their homelands that ratify the Northern reader's clichéd expectations. ${ }^{15}$ The enduring North-South divide continues to influence the evolution of creativity, but new regional networks are now successfully pushing back. The Tahitian Chantal Spitz eloquently explains the frustration of those who must constantly justify why they write and why they write in French:

When we write and wish to be published, we have only two choices. Either write in Tahitian, and hardly anyone will publish us. Even the Tahitian Academy is at pains to publish its writings, which are viewed as second-rate. Or we can write in French ... and if we want to be published in France, we must be culturally relevant and politically correct; that's when we'd have the chance. Or else, we must conform to the high standards for high literature held by the French. Furthermore, writing goes against the myth of the Polynesian as a child whose hand needs to be held. ... It is not because we are an oral people that we do not write. Some of us have internalized this excuse. So we feel we need to justify ourselves, justify our writing, because we come out of an oral culture. But does a Frenchman ever get asked why he writes? ... If we just produce polite literature that adds nothing to the debate, it is useless. We must write to talk about things, to make them known and acknowledged, colonization, nuclear testing. . . . But everyone must 
find his or her own way, so long as we don't just parrot what we were taught. We must be Tiama. Which does not mean independent, it means "upright and clean" [free]. In any case, we must never give lessons; only write what we think.

(Spitz; our trans.)

Caught between conflicting expectations, Spitz denounces the pressure to be "polite" so as to achieve greater visibility. In her fiction, articulations of local realities recalibrate Northern notions and bring deeper awareness of the role Pacific insular peripheries have played in the geopolitics of colonialism and nuclear testing. Her engagement with issues of language and power contributes to the larger debate about what makes French a global rather than merely European language and about how effective a vehicle it has been for expressing the distinct subjectivities of writers from across the former colonial empire.

Reflecting on the link between publication and power in Ten Books That Shaped the British Empire, Antoinette Burton and Isabel Hofmyer reassert the need to revise conceptions of belonging and difference that are expressed in the colonial language. They argue that "books ... were sites of deterritorialized subjectivity. Though produced in the context of empire, they were a refuge for those who did not necessarily think in conventional imperialist or even nationalist idioms" (10). Spitz makes the same point for the postcolonial period when she shares her irritation at readers who do not grant francophone writers the right to flexible subjectivities. In her view, books written in French and published in France do not necessarily transmit Northern biases. The global nature of French resides in its ability to embody a translocal consciousness that exceeds metropolitan conventions and conveys new understandings. When oral vernaculars and new aesthetics transform French, the resulting creative idioms, structures of meaning, and forms of expression are not just a remnant of imperial power; they now rightfully belong to the cre- ators who have appropriated and colonized the imperial tongue, even if their relation to it remains fraught because of the social and political pressures that Spitz denounces.

Like the Polynesian Spitz, francophone Indian Ocean writers have reflected extensively on the use of French. La langue (the physical tongue and the linguistic system) remains a major concern for them, as it is for the academic critics Valérie MagdelaineAndrianjafitrimo and Carpanin Marimoutou of the Université de La Réunion, who have discussed the linguistic leitmotifs and stylistic innovations of vernacular authors whose native tongues are devalued, just as the communities that speak them go unrecognized. The Mauritian novelist and dramatist Shenaz Patel, a winner of the Beaumarchais Prize, thematizes and allegorizes the issue in Paradis blues, a book published, like Elbadawi's Un dhikri pour nos morts, by Vents d'Ailleurs. Patel's dramatic poetic text is based on interviews she conducted with Miselaine $\mathrm{Du}$ val, an actor and humorist who founded $\mathrm{La}$ Troupe Komiko, a local theater group that uses mostly Mauritian Creole (Kreol Morisien). Paradis blues is a true collaboration, a dense and powerful monologue delivered by Duval in her autofictional, deeply disturbing, and spectacular one-woman show. ${ }^{16}$ It decries the enduring postcolonial subjection of women and was first performed to great acclaim in 2009 in Mauritius and then in Limoges, France. Patel was commissioned to write the text by Duval and the stage director Ahmed Madani. Juxtaposing the Creole vernacular with a limpid French style, Patel gives agency to a narrator emblematic of the long-silenced figures of colonial history and native patriarchy.

On the face of it, this is a text about gender violence and the de-meaning of a woman's voice. But the female persona is also an allegorical figure for the internalized and enduring denigration of the Creole mother tongue. The narrator, Mylène, is interned in a 
psychiatric hospital, where she reflects on the brutal physical and psychological treatment she has received from family and society, who instilled in her the belief that her sole purpose in life is to shut up and find a mate, preferably a white Western foreigner. She has been taught that she must always hold her ugly, dirty tongue:

Langue. Langue. Tu dois savoir la tenir. Ta langue. Langue de vipère. Bave. Crapaud. Pas un prince Charmant. Non. Un crapaud, un vrai. Vert et de pustules couvert. Non mais t'as vu ta gueule, pétasse! Tiens, prends ça. Prends ça dans ta gueule. Tu vas la fermer? Ta gueule, tu vas la fermer?

Tongue. Tongue. You should learn to hold it. Your tongue. Your spiteful, forked tongue. Drool. Toad. Not a Prince Charming. No. A toad, a real one. Green, and covered with pimples. Hey, you look like shit, you, slut! Take that! Take that on your trap! Shut up! Will you shut the hell up?

The abusive epithets and animal imagery reduce her to a monstrous self with a despised tongue. The theme culminates with the mother's death, as Mylène recalls how she accompanied her mother to the market, the bazaar where she first encountered slabs of butchered beef:

Section viande. L'odeur crue du sang. Ces quartiers alignés sur le marbre blanc. Les nuées de mouches animant la chair blême d'une étrange ondulation. À côté de l'amas flaccide d'une cervelle de bœuf qui ressemblait à un lacis d'intestins, cette chose, cette masse rouge, compacte et ferme, sans os, comme un bloc de sang coagulé. ... C'est quoi, maman? Dis, c'est quoi, cette chose?

Une langue, dit-elle, une langue de bœuf.

Meat section. The raw smell of blood. Beef parts aligned on the white marble. Clouds of flies create a strange ripple over the pale flesh. Next to a flaccid ox brain that looked like a tangled web of tripe, this thing, this red heap, compact and firm, boneless, like a lump of coagulated blood.... What's this, Ma? Tell me, what's that thing?

A tongue, she says, an ox tongue.

The revolting image of the bloody tongue, separated from the body, prefigures the final episode, in which we discover the reason for Mylène's psychiatric internment: "Arracher sa langue, vous vous rendez compte, arracher la langue de sa mère. Sur son canapé mortuaire. Certaines personnes ne respectent rien. Le sang, le sang qui s'est répandu, paraît qu'il était noir, mais noir d'encre" 'Pulled out her tongue, can you believe it, pulled out her own mother's tongue. On her funeral bed. Some people have no respect. The blood, the blood that spread, they say it was black, black as ink' (51). By means of this symbolic castration of the phallic, self-hating mother who verbally abused her, Mylène regains a measure of psychological freedom and rejects the passive role of the good daughter and faithful Penelope who patiently awaits the return of Ulysses: "Je crache sur Pénélope. Cette conne" 'I spit on Penelope. That cunt' (50). Mylène is revived as she lets language flow freely and deliriously out of her: "Les mots me sauvent. / Les mots me placent dans la vie. Intensément" 'Words save me. / Words bring me to life. Intensely' (52). Finally able to give free rein to her creativity, she revels in the language that she can now own. She lets the words tumble out of her throat and mouth, words that articulate the telling of "the islands that inhabit us. The island that we are":

Parfois les mots m'arrivent comme des marcheurs pressés. Dans ma gorge, ils se bousculent. Alors j'ouvre grand la bouche, et je laisse place à leur clameur. Avec eux je dis que je ne serai pas une figurante. Non. Sur le devant de la scène, je monterai. Ivre de lumière. Saoulée de larmes et de rires. J'ouvrirai grand la bouche pour que les mots cascadent et résonnent. Avec eux je dirai ces îles que nous portons en nous. Ces îles que nous sommes. Et je 
chanterai notre dérive, un peu désordonnée sans doute, mais impatiente, mais obstinée, notre dérive volontaire pour recréer, au milieu de tout ce bleu, le continent rêvé...

\section{C'est sûr, je n'attendrai pas plus longtemps.} Ce soir, je fracasse la cloche.

Sometimes words come to me like hurried hikers. They bump along my throat. So I open my mouth wide, giving way to their clamor. With these words, I say that I will not be just an extra. No. I will take center stage. Drunk with light. Soaked with tears and laughter. I will open wide my mouth for words to cascade and resonate. With these words, I will tell the islands that inhabit us. The islands that we are. And I will sing our drifting course [dérive], our somewhat aimless yet impatient, yet stubborn drift, our resolve to drift closer together so we can recreate, in the midst of all this blue, the dreamed-of continent ...

For sure, I won't wait any longer.

Tonight, I shatter the bell.

(54; our emphasis)

Throughout the text, Patel's imagery and creative rhythm evoke the abject and lasting legacies of slavery, echoing Aimé Césaire's references in Notebook of a Return to the $\mathrm{Na}$ tive Land to the suicidal tongue swallowing of Africans during the Middle Passage and his rewriting in A Tempest of Caliban as a vocal, rebellious, and eloquent speaker who vomits the language he was taught. The network of intertextual allusions creates a metaphoric echo chamber that denotes the very real global dimensions of francophonie, as well as the potential for creative solidarity among distant, transcolonial regions with similar Creole archipelagic histories that have resolved to "drift" into greater collaboration.

In her afterword, Patel stresses what we would like to call here the condition insulaire, or islandness, that Mylène embodies as she reflects on the limits of la langue when it attempts to capture the singular nuances of the time and space of creolized archipelagoes with their legacy of conquest by successive imperial powers. ${ }^{17}$ Patel reiterates the importance of the articulate self that explores and translates into writing the layers that result from that history, obfuscated though they may have been by the dominant view of insularity as static and bounded:

\section{Ces îles que nous portons en nous,} ces îles que nous sommes...

C'est au détour d'une image, parfois, qu'échoppent nos silences...

Dans l'œil de l'autre ou, plus intensément, dans notre propre regard, une image, soudain, qui fait grain de sable....

Peut-être est-ce de cela que naît, un jour, l'écriture. De cet intime sentiment de décalage.

Écrire pour apprivoiser l'idée que chacun de nous, dans sa vérité singulière, est au fond non pas double mais multiple.

These islands that inhabit us these islands that we are...

The flash of an image, sometimes, gives shape to our silences...

In the other's eye or, more intensely, within our own gaze, an image can suddenly act like a grain of sand....

Perhaps this is how writing comes into being one day. From this intimate feeling of décalage.

.........

To write in order to cultivate the idea that for each of us, our individual truth is after all not just double but multiple.

Patel muses that her creativity is rooted in the sense of décalage, or disconnection and displacement, produced by the sudden "flash of an image," the stereotype that can "act like a grain of sand" and so give birth to the pearl of a counterfiction capable of shattering the silences and misprisions surrounding those whose liminal identities far exceed the categorical frameworks of empire. Once their complexities are enunciated, these identities become part of a new weave in which multiplicity is perceived 
in conjunction with the multidirectional memories and solidarities it allows.

In this francophone cultural weave, the Malagasy writer Jean-Luc Raharimanana expresses what the Comoran Elbadawi, the Tahitian Spitz, and the Mauritian Patel imply as they work across distant spaces to "fracasse[r] la cloche" 'shatter the bell' (Patel 54) that muffles the truths of the marginalized. In Les cauchemars $d u$ gecko, he writes: "ce n'est pas la réalité qui nous isole du monde, mais la fiction sur nous plaquée, l'impossibilité de contredire malgré nos cris et nos dénégations" 'it is not reality that isolates us from the rest of the world, but the fiction imposed on us, our inability to argue against it despite our cries and denials' (8). The disconnect between lived or felt reality and externally imposed truths motivates forms of writing that can challenge the clichéd view of islands as isolated and insignificant. It would therefore behoove us as critics to recognize the contours of this alternate geography of transnational connections and minor relations that produce strong mutual affirmation. As they knit a common transcolonial francophone destiny by means of the precise, small narratives and significant details that compel their real and imagined readers near and far, these archipelagic voices reveal that they are heirs to Césaire's lyrical and volcanic grand cri. Together, their imaginative perspectives trouble received definitions of the global.

The work this writing performs in the world stretches academic notions of world literature beyond the logic of mere inclusion toward an acknowledgment of the transformative theoretical potential of transversal comparisons among ultraminor writers in the global South. To think the world with these archipelagic francophone voices, and to do so transversally, is to underscore the importance of dialogue, collaboration, and solidarity, something we have endeavored to do in this essay as we question, with Raharimanana, the imposed correlation between mean- ingfulness and origin, visibility and agency, and especially originality and individuality. Looking at the world in fine from the standpoint of its smallest insular locations can thus become our answer to the big data sets that can only capture a panoptic version of reality.

\section{Tactical Choices, Ethical Positions}

We now want to return briefly to Devi's interview and to what it reveals about authorial agency and the professional negotiation of visibility. Devi makes clear that gaining access to prestigious publishers in metropolitan centers often remains a fantasy for writers from small places. The detours and byways of her successful publication journey as a francophone Indo-Mauritian illustrate the ambiguities and the constraints that weigh on minor writers as they develop, in response to the expectations of major publishers, survival tactics that can include irony, candor, dissimulation, and humor. ${ }^{18}$

Brouillette aptly points out that "literary production is influenced by the development of authorship as a profession and by the process through which writers consume images of themselves and reinterpret those images in order to negotiate and circulate different ones" (Postcolonial Writers 2). Like Salman Rushdie and J. M. Coetzee (two of the writers singled out by Brouillette), Devi crafts a complex authorial persona while working within the system, a persona that enables her to succeed and thus also gives her the freedom to denounce a process that strews the road to recognition with pitfalls. She projects an image of herself as a trailblazer who is candid about the "compromises entailed" in her achieving recognition (Devi 119) but wants to fully support her peers' struggle for legitimation. Her comments indicate that far from identifying with the type of creative worker promoted by neoliberalism and examined by Brouillette in her exposé Literature and the Creative Economynamely, "the model of the asocial or antisocial 
flexible individualist" (4) - Devi is well aware of the geohistorical and economic contingencies that govern the success of regional works that "are no less good than those of others who find publishers more easily" (Devi 119). She draws attention to the fact that complete artistic autonomy was never an option for Indian Ocean writers, who have always had to rely on transregional intellectual and publishing networks. Here, solidarity trumps the mere management of neoliberal cultural commerce; collaborative endeavors point instead to the "old roots" of creativity: "sensitivity to others' conditions of existence" and "incrimination of any model of the self that assumes and privileges its egoism." ${ }^{19}$ The South-South island networks we have showcased demonstrate the ironies of linguistic clichés that continue to feed neoliberal misprisions about creativity understood as "the fundamentally insular expression of one's personally directed passionate devotion to ... 'the work'" (Brouillette, Literature 7; our emphasis). Unsurprisingly, a strong disconnect inevitably develops between intellectuals from networked island nations and the Western promoters of the professional artist, since the sedimented etymologies of Indo-European languages have thoroughly othered the concrete realities and lived experiences of insularité, erroneously equating islandness with isolation, remoteness, and inaccessibility.

Brouillette's argument that the professionalization of authors is one of the factors accounting for the recuperation of marginal voices by metropolitan publishers raises too many ethical questions to unpack here. Yet, as the example of Devi indicates, authors readily adopt subversive tactics-rather than engage in frontal opposition-to resist the capitalist logics of the creative economy and to produce the "alternative visions of a self not sufficient to itself" (Brouillette, Literature 5). Given the uneven terrain of the literary marketplace, multilingual francophone writers know that the only way to make their transcolonial linguistic prac- tices globally legible is to resort to approaches that allow them simultaneously to mimic and to challenge the creative norms of the gatekeepers of the dominant aesthetic, something Devi's entire oeuvre vividly illustrates. ${ }^{20}$

As writers gain access to global distribution circuits, they transform the metropolitan publishing landscape into a site where minor voices are ultimately empowered to create models that counter the asocial "insular" creator deplored by Brouillette. More equal, or at least less asymmetrical, collaborations between editors and multiply positioned writers become possible and succeed at partially undoing the hierarchies at work on the uneven terrain of the market. The case of Vents d'Ailleurs is worth considering in some detail because it exemplifies the emerging horizontal conversations that testify to the evolving role of minor writers and their alternative metropolitan publishers within the broader conception of littérature-monde, or world literature.

The press's Web site announces its mission:

We publish books that come out of other cultures, near and far; we are convinced that knowledge of the world's cultures can help build a better and more intelligent society. Vent d'Ailleurs's catalog builds bridges to these other realms of the imagination and offers books that enrich human beings in their quest for humanity. ... We belong to the Alliance of Independent Publishers in order to contribute to the elaboration of a global network that advocates a certain idea of creative literary publishing, and to support the idea that books and the activity of reading open windows onto the world and are not just consumable, interchangeable, and disposable products. We are an independent publisher of creative works, and we defend bibliodiversity because a plethora of books is not a true sign of the diversity and plurality of ideas. (“Qui sommes-nous?")

This vision of a transcultural vehicle for literary dialogue that can nurture "a better and more intelligent society" supports the idea 
that books are not just material objects but, in Burton and Hofmyer's words, "path-makers for the circulation of ideas and discourses" and "material agents" (9) that work toward the reevaluation of the place occupied by the differentiated visions and deterritorialized subjectivities of these ailleurs 'elsewheres' to which the publisher is building "bridges."

Vent d'Ailleurs's ultimate goal is to convert what was once the centripetal attraction of established houses, directed toward the incorporation of postcolonial exoticism, into reverse, centrifugal pathways of relation that align with new intersectional and transversal geographies. The press's code of ethics advocates an approach that not only promotes epistemological justice in the politics of francophone publishing but also makes a statement about sustainability and inclusivity, or "bibliodiversity," warning against the commodification and irresponsible consumption of books with no new ideas. Each series in its portfolio articulates a particular philosophy of inclusion that contributes to a concrete and interactive definition of world literature. The series Fragments, edited by Raharimanana, announces that its main purpose is to give a platform to "marginal literatures.... Singular voices that traverse our time and express our world. When, from the silence of marginal spaces, fragmented images of reality and fragmented dreams of humanity are unleashed. A series that listens" ("Fragments"). Putting peripheral voices into dialogue, Fragments strives to create a space where authors can take control of editorial matters and overcome losses felt "from one shore to the other" (Elbadawi 7). Pulsations, which published Paradis blues, emphasizes the idea of change in the back matter of this book by playing on the polysemy of the verb entendre, which can mean to hear, to intend to, and to understand: "Pulsation is a series that seeks [entend] to transmit fictions from every horizon; to echo the social, cultural, and political changes of our world; and to understand better the wide-ranging universes that sometimes brush up against ours, whereas we often overlook their ways of living, thinking, loving, and writing" (Patel 63). These editorial mission statements express the generous wish to be attentive to the many evolving creative universes of francophonie. They goad readers to "open big" their ears and listen to the world. The platform provided by Vents d'Ailleurs from its own decentralized creative base in La Roque d'Anthéron is thus a fitting home for Elbadawi's anguished cri de coeur about Western complacency and the media blackout surrounding his archipelago. It suggests many new avenues for creatively reimagining our monde.

\section{NOTES}

1. All translations are ours, unless otherwise noted.

2. For a discussion of the transcolonial in relation to the postcolonial and the minor transnational, see Lionnet and Shih 1-26 and Lionnet, "Narrating."

3. To cite three examples among many, a political scientist at the University of California, Los Angeles, puts the Senegalese film La pirogue, directed by Moussa Touré, on the syllabus of his general education course on migrations; a professor of government at Harvard University assigns Moroccan novels when teaching about North African politics; and a professor at the Harvard Business School uses Chinua Achebe and Sophocles to encourage students to develop their own workable definition of moral leadership, and she has published an instructor's guide for her course on the moral leader (Sucher, Teaching and "Teaching").

4. This figure does not include the 60,000 to 100,000 clandestine migrants living in Mayotte (Capron). Domien is coined from DOM and describes the inhabitants of overseas departments of France.

5. For a succinct explanation of the origin of the term kwassa-kwassa, see Bragard's fine analysis of Charles Masson's graphic novel Droit du sol 'Birthright' (194-95).

6. Ranavaison defends francophone creativity as a means of forging regional links.

7. As Simon Gikandi stresses in a PMLA Editor's Column, "One of the most important developments in literary studies ... has been the turn to questions of human rights" (521).

8. We echo the title of Jamaica Kincaid's critique of colonialism and tourism in Antigua. 
9. Richard Florida's book The Rise of the Creative Class examines the diversification of work and play, the importance of considering "quality of place" rather than simply quality of life (231), and the emergent, interrelated connections that create new commercial knowledge systems.

10. For Jean-François and Kee Mew, Western centers produce an incomplete version of Indian Ocean postcolonial literatures while making local and indigenous literary expressions invisible.

11. See Lionnet, "Universalisms," for a detailed critique.

12. The essays in Translocal Geographies: Spaces, Places, Connections, edited by Brickell and Datta, reflect the developing discussion among social scientists about the concept of the translocal.

13. For Nancy there is no equivalence between the French monde, which is ever-evolving, and the English world, understood as a finite globe.

14. The sociologist Ulrich Beck uses the term "transnational place polygamy" to describe the simultaneous connection to multiple spaces of belonging (73).

15. Kee Mew and Jean-François demonstrate how, historically, the definition and recognition of Mauritian literature have been associated with Paris, not just as the editorial center of francophonie but also as the site that dictates value and canonizes French-language literature, which it claims to define and disseminate.

16. The production brochure provides staging information and a stunning photograph of the actress in character (Madani).

17. See also Pamila Gupta's useful discussion of islandness ("Anthropologies" and "Island-ness").

18. We use tactics as Michel de Certeau defines it in The Practice of Everyday Life.

19. Brouillette echoes the formulations of Luc Boltansky and Eve Chiapello (Literature 8).

20. Lionnet's comprehensive study of Devi's work highlights this aspect of it (Écritures 90-112, 173-204, 240-84).

\section{Works Cited}

Beck, Ulrich. What Is Globalization? Polity, 2000.

Bragard, Véronique. "Shipwrecking the World's 'Wretched Refuse': Spectres of Neocolonial Exclusion in Carl de Souza's Ceux qu'on jette à la mer and Charles Masson's Droit du sol." Shipwreck in Art and Literature: Images and Interpretations from Antiquity to the Present Day, edited by Carl Thompson, Routledge, 2014, pp. 187-203.

Brickell, Kathryn, and Ayona Datta, editors. Translocal Geographies: Spaces, Places, Connections. Ashgate, 2011.

Brouillette, Sarah. Literature and the Creative Economy. Stanford UP, 2014.

- Postcolonial Writers in the Global Literary Marketplace. Palgrave Macmillan, 2007.
Burton, Antoinette, and Isabel Hofmyer. Ten Books That Shaped the British Empire: Creating an Imperial Commons. Duke UP, 2014.

Capron, Alexandre. "Immigration clandestine à Mayotte: Le récit d'un comorien." France 24, 26 Feb. 2015, observers .france24.com/fr/20150226-immigration-clandestine -mayotte-recit-comorien-controle-frontiere-france.

Certeau, Michel de. The Practice of Everyday Life. 1984. 3rd ed., U of California P, 2011.

Damrosch, David. What Is World Literature? Princeton UP, 2003.

Devi, Ananda. "Ananda Devi as Writer and Translator: In Interview with Julia Waters." Intimate Enemies: Translation in Francophone Contexts, edited by Kathryn Batchelor and Claire Bisdorff, Liverpool UP, 2013, pp. 117-23.

Ekotto, Frieda, and Kenneth W. Harrow. "Rethinking African Cultural Production.” Introduction. Rethinking African Cultural Production, edited by Ekotto and Harrow, Indiana UP, 2015, pp. 1-16.

Elbadawi, Soeuf. Un dhikri pour nos morts: La rage entre les dents. Vents d'Ailleurs, 2013.

Florida, Richard. The Rise of the Creative Class. Basic Books, 2012.

"Fragments." Vents d'Ailleurs, 15 Aug. 2016, www .ventsdailleurs.fr/index.php/catalogue/category/ fragments.

Gikandi, Simon. "Editor's Column: In the House of Criticism.” PMLA, vol. 128, no. 3, May 2013, pp. 521-29.

Glissant, Édouard. Traité du Tout-monde. Gallimard, 1993.

Gupta, Pamila. "Anthropologies of Islandness in the Indian Ocean." Créolité, créolisation: Regards croisés, edited by Laurence Pourchez, Archives Contemporaines, 2013, pp. 185-95.

__. "Island-ness in the Indian Ocean." Eyes across the Waters: Navigating the Indian Ocean, edited by Gupta et al., U of South Africa P, 2010, pp. 275-85.

Jean-François, Emmanuel Bruno, and Evelyn Kee Mew. "Les auteurs de l'ombre du champ littéraire mauricien: Entre critères de légitimation et stratégies de reconnaissance." Loxias, vol. 37, 2012, revel.unice.fr/ loxias/?id=7057.

Kee Mew, Evelyn, and Emmanuel Bruno Jean-François. "Paris et sa représentation de la littérature mauricienne d'expression française." La tortue verte, vol. 1, Jan. 2012, pp. 38-54, www.latortueverte.com/ DOSSIER\%201Ce\%20que\%20Paris\%20fait\%20aux\%20 litteratures\%20francophones\%20janv\%202012.pdf.

Kincaid, Jamaica. A Small Place. Farrar, Straus and Giroux, 1988.

Lalami, Laila. Hope and Other Dangerous Pursuits. Algonquin Books of Chapel Hill, 2005.

Le Bris, Michel, and Jean Rouaud. "Manifeste pour une littérature-monde en français." Le monde des livres, 16 Mar. 2007, p. 2. 
Lionnet, Françoise. Écritures féminines et dialogues critiques: Subjectivité, genre et ironie. L'Atelier d'Écriture, 2012.

__ . "Littérature-monde, francophonie et ironie: Modèles de violence et violence des modèles." Littératures francophones: Parodies, pastiches, réécritures, edited by Lise Gauvin et al., ENS Éditions, 2013, pp. 119-38, books.openedition.org/enseditions/2451.

__ . "Narrating the Americas: Transcolonial Métissage in Maryse Condé's La migration des coeurs." Mixing Race, Mixing Culture: Inter-American Literary Dialogues, edited by Monika Kaup and Debra Rosenthal, U of Texas P, 2002, pp. 65-87.

_- "Universalisms and Francophonies." International Journal of Francophone Studies, vol. 12, nos. 2-3, Dec. 2009, pp. 203-21.

Lionnet, Françoise, and Shu-mei Shih. Minor Transnationalism. Duke UP, 2007.

Madani, Ahmed. "Plaquette d'information Paradis blues." Madani Compagnie, www.ahmedmadani.com/IMG/ pdf/Plaquette_Paradis_blues.pdf.

Magdelaine-Andrianjafitrimo, Valérie. "Une mise en scène de la diversité linguistique: Comment la littérature francophone mauricienne se dissocie-t-elle des nouvelles normes antillaises?" Glottopol: Revue de sociolinguistique en ligne, vol. 3, Jan. 2004, pp. 14265, glottopol.univ-rouen.fr/telecharger/numero_3/ gpl312magdelaine.pdf.

Marimoutou, Carpanin. "Poétique du mélangue et du malang dans le roman réunionnais contemporain: $\grave{A}$ l'angle malang: Les maux d'ici de Jean-Louis Robert." Revue de littérature comparée, vol. 318, no. 2, Apr.June 2006, pp. 213-34
Masson, Charles. Droit du sol. Casterman, 2009

“Mayotte." Wikipédia, 12 Aug. 2016, fr.wikipedia.org/ wiki/Mayotte.

Nancy, Jean-Luc. "La métamorphose, le monde." Rue Descartes, vol. 64, no. 2, 2009, pp. 78-93.

Patel, Shenaz. Paradis blues. Vents d'Ailleurs, 2014.

“Qui sommes-nous?” Vents d'Ailleurs, 15 Aug. 2016, www .ventsdailleurs.fr/index.php/la-maison-dedition.

Raharimanana. Les cauchemars du gecko. Vents d'Ailleurs, 2011

Ranaivoson, Dominique. "Qui entendra les Comoriens? Ou comment une littérature francophone peut sauver de l'isolement." E-France: An Online Journal of French Studies, vol. 2, 2008, pp. 189-208, www.reading.ac.uk/ web/FILES/e-france/Ranaivoson.pdf.

Sommer, Doris. The Work of Art in the World. Duke UP, 2014.

Spitz, Chantal. "Entretien avec Chantal Spitz." Interview by Nicolas Cartron. Île en Île, 27 Feb. 2002, www.lehman .cuny.edu/ile.en.ile/paroles/spitz_entretien.html.

Sucher, Sandra J. Teaching the Moral Leader: A LiteratureBased Leadership Course. Routledge, 2007.

. "Teaching the Moral Leader." Interview by Sarah Jane Gilbert. Working Knowledge: The Thinking That Leads, President and Fellows of Harvard College, 17 Nov. 2007, hbswk.hbs.edu/item/teaching-the -moral-leader

Torre, Henri. "Mayotte: Un éclairage budgétaire sur le défi de l'immigration clandestine." Rapport d'information 461. Sénat, 2007-08, www.senat.fr/rap/r07-461/ r07-461.html. 